\title{
Seeing Red and Feeling Blue: Social Commentary and Protest in the Work of Michael Reed
}

DOROTHEE PAULI

\begin{abstract}
Accounts of politically inspired art occupy the margins of New Zealand art history. The career of Michael Reed (born 1950, Christchurch) offers an opportunity to discuss how a New Zealand artist has responded to shifts in $20^{\text {th }}$ and early $21^{\text {st }}$ century global debates regarding social justice, economic exploitation, cultural domination and war. He works across a range of mainly print-based techniques but has also found international recognition for his technically innovative 'medals of dishonor.' Through his frequent involvement in collaborative projects, Reed has become part of national and international networks of artists who attempt to speak for the many victims of geo-political power struggles.
\end{abstract}


"In a decaying society, art, if it is truthful, must also reflect decay. And unless it wants to break faith with its social function, art must show the world as changeable. And help to change it." Ernst Fischer (1899-1972)

By his own admission, Michael Reed is an artist who is hard to pin down. He displays a magpie's appetite for trying new techniques and new directions in his creative practice, underpinned by a life-long commitment to the ever-versatile medium of print. In a career spanning nearly five decades,

he has never been stuck for ideas or the right ways to express them. He has been exhibiting steadily since the 1970s, often alongside his better-known contemporaries such as Barry Cleavin, Ralph Hotere, Gordon Walters and Don Peebles. ${ }^{1} \mathrm{He}$ is the recipient of numerous national and international awards, and his work, which has been shown in South America, the United States, Europe, Australia, Cuba and Japan, is held in collections all over the world, including the British Museum. ${ }^{2}$ Why then does his name not appear more frequently in New Zealand's mainstream arts publications?

The answer to that question may lay in the fact that the work he is best known for is often politically motivated, international in its focus and print-based. Given the current debates on the political, economic, and environmental future of this planet, it is perhaps timely to broaden current perspectives on this aspect of contemporary New Zealand art practice. Therefore, this article will discuss how Reed, born in 1950, right on the mid-point of the $20^{\text {th }}$ century, responded to certain aspects of growing up and maturing as an artist in New Zealand at that time, and how he moved on from there to acknowledge the cultural and ideological shifts associated with the rise of neo-liberal politics and post-colonial thinking. To this day, he brings to his work the necessary personal attributes required of an artist intent on delivering uncomfortable messages. He has been described as "tenacious, methodical and uncompromising" and he freely admits that the production of "visual sedatives for the established middle-class art print market" 5 is not for him. At 71 , he is still not ready to bend to the prevailing trends of New Zealand's art market and continues to lend his voice to those not often heard in the ongoing global debates on social justice.

In the first instance, Reed's instinctive and often very overt responses to recent historical shifts need to be considered in the context of his upbringing in post-war New Zealand. His interest in art and design did not develop against a comfortable middle-class background, and the social context of Christchurch in the 1950s and 60s provided little encouragement or inspiration in that regard. His recollections paint a rather restrained picture of his younger years, largely devoid of the opportunities a more privileged set of circumstances may have been able to provide for a child with artistic sensibilities. His working-class parents expected him to leave school at fifteen. His father especially thought of his adult son as over-educated, obviously sensitive to the class divide that was opening up between them. That said, his parents' left-leaning political views explains the trajectory of much of Reed's later work.

Reed's art training began at Hillmorton High School, located in the south-east of Christchurch, and one of the many public high schools established in 1960s New Zealand to meet the educational needs of the baby-boomer generation. ${ }^{6}$ To this day, Hillmorton High School carries no particular prestige in a city where the colour of one's school tie forms the basis of significant social and economic networks. It was there that Reed had a lucky break insofar as his art teacher was Ray Neumann. In Reed's own words Neumann was 'a god-send'7 enthusiastic, supportive, tolerant, and a decisive influence. He introduced Reed to a wide range of pre-dominantly European artists, including the so-called Kitchen Sink School of British post-war social realism, and especially John Bratby. Neumann also encouraged Reed to study the work of Gustav Klimt, Egon Schiele, Oskar Kokoschka, the German Expressionists and David Hockney, and showed him examples of Scandinavian modernism to feed his student's early interest in architecture. He was also Reed's first printmaking teacher, introducing him to the linocut, woodcut and screen-printing on textile. Although somewhat sceptical of academia himself, Neumann encouraged Reed's educational aspirations, and perhaps most importantly, he persuaded Reed's parents to let their son stay on at high school past the age of fifteen. This was helped by the fact that Reed, who was otherwise a less than enthusiastic pupil, completed the Fine Arts Preliminary (then the equivalent of bursary art covering sculpture, design, painting, drawing and some photography) during sixth form, and, having received a studentship at the end of that year, transferred to the Ilam School of Art at the age of seventeen. ${ }^{8}$

Reed did not arrive at Canterbury University with any fixed notion as to what he wanted to specialise in and completed the required general first-year course in $1967 .{ }^{9}$ It was then he met some his better-known peers, including the sculptor Graham Bennett, who was studying photography and design, and Chris Booth, who left llam after the first 
year of study to work for Barbara Hepworth in the UK. His fellow students also included the painters Philip Clairmont, Gerda Leenards, Sally Burton and the photographer Mark Adams. He also came to know some of the older students, including Ross Gray, Gavin and Vivian Bishop, Shona Cowan, Brett de Thier, Peter Ridder and Robyn and Peter Belton. At the time, painting, which had always been a strong department at the llam School of Fine Art was by far the most popular option, ${ }^{10}$ which was one of the reasons Reed decided not to join that class. ${ }^{11}$

In 1968, Reed briefly considered studying textiles, but as that department was shutting down, he chose to follow his interest in printmaking instead. He had previously seen and was impressed by the work of Barry Cleavin, and therefore enrolled in John 'Jack' Knight's printmaking course. Reed remembers Knight (1913-1981) as a competent academic and painter, and as an amiable, but hands-off tutor. It was Derek Mitchell, the only other full-time printmaking student at the time, and ahead of Reed by some years, who was the most supportive and taught him technique, namely intaglio and lithography. At the time, screen-printing was still considered a highly commercial medium, and Reed studied this particular process independently. His minor studies covered graphics, with an emphasis on typography, painting (with Ted Francis) and photography. Being one of two full-time printmaking students greatly appealed to Reed. He respected Mitchell and preferred working on his own, more or less free from the usual art school distractions. That said, Reed did not isolate himself entirely from like-minded people of his generation.

In his first year at university, and in keeping with his left-leaning political views and pacifist ideals, he joined local anti-Vietnam war protests, which precipitated his involvement with the general anti-war movement. To avoid conscription, then still the law in New Zealand, he registered as a conscientious objector. He also began to understand the destructive consequences of racism, and the challenges faced by the United States Civil Rights movement. ${ }^{12}$ However, his developing political awareness did not immediately translate into the politically motivated work of the kind he is now associated with. Instead, his graduation portfolio points to another consistent aspect of his work, an eye for effective composition and a seductive use of colour. An example of this is the award-winning Joybox (1969, intaglio and colour pencil, collection of the artist). ${ }^{13}$ Here a square box set against a biomorphic, embossed background, is accentuated by an eye-catching band of rainbow colours, an approach that resurfaced several other prints of this era. It reflects the

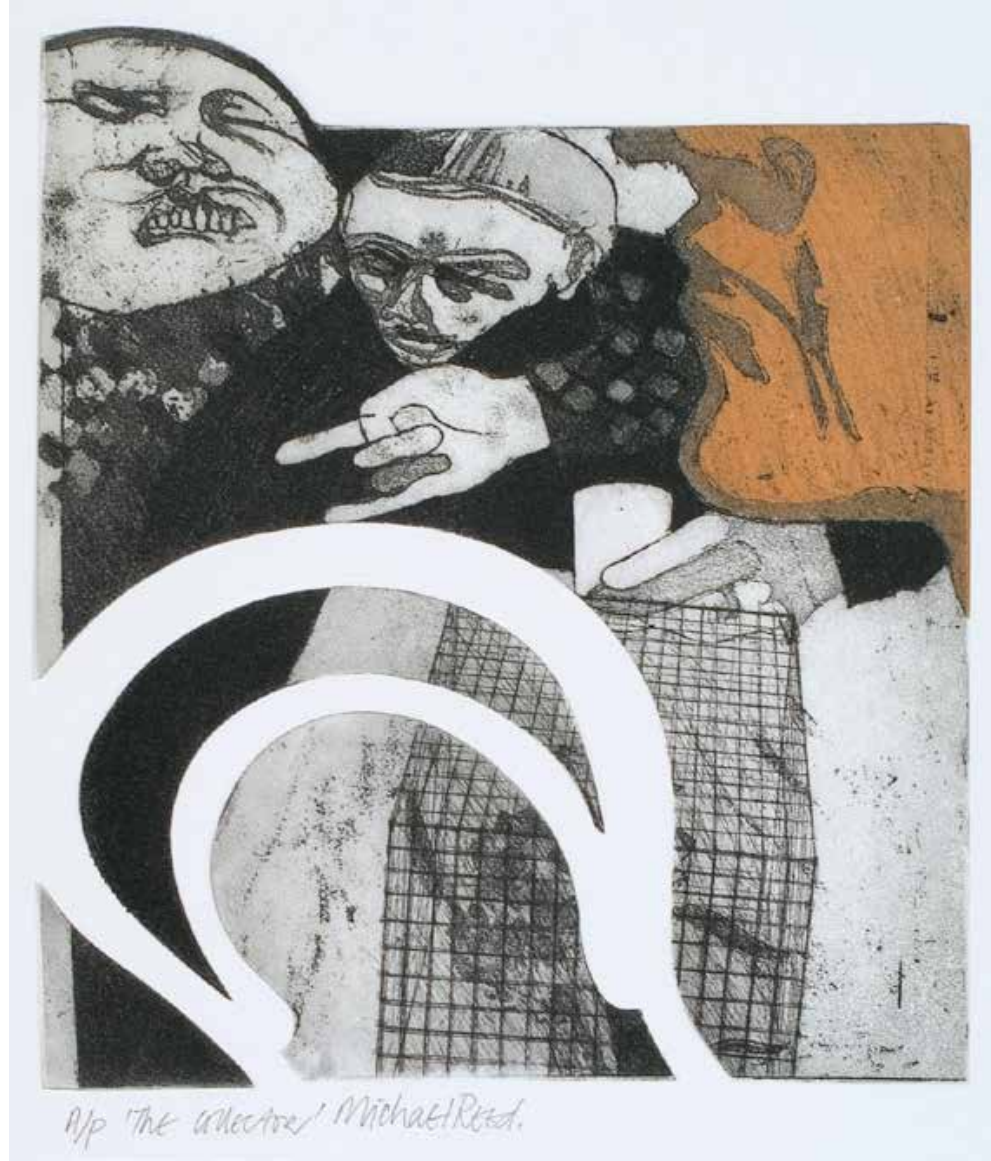

FIGURE 1. The Collector, 1976, etching, 378x557mm, Christchurch Art Gallery Te Puna o Waiwhetu.

artist's interest in British Pop Art, which also appeared in some of the compositional elements of The Collector (Figure 1). This early intaglio work combines figurative elements with an ambiguous organisation of pictorial space, and the use of block colour as a balancing element. By the 1970 s then, Reed had developed a standard of technical competence in printmaking that allowed him to mix various printmaking techniques in at times complex compositions based on expressive mark making.

Reed's concern for social justice first appeared in his work when he began to support Trade Aid in the late 1970s, and more notably so during the Springbok Tour of 1981. At the time he not only joined the protest movement but also designed and printed a poster for a Christchurch protest march. The wordless placard shows a solemn African woman and three undernourished children, their eyes highlighted 


\title{
Seeing Red and Feeling Blue: Social Commentary and Protest in the Work of Michael Reed
}

DOROTHEE PAULI

\begin{abstract}
Accounts of politically inspired art occupy the margins of New Zealand art history. The career of Michael Reed (born 1950, Christchurch) offers an opportunity to discuss how a New Zealand artist has responded to shifts in $20^{\text {th }}$ and early $21^{\text {st }}$ century global debates regarding social justice, economic exploitation, cultural domination and war. He works across a range of mainly print-based techniques but has also found international recognition for his technically innovative 'medals of dishonor.' Through his frequent involvement in collaborative projects, Reed has become part of national and international networks of artists who attempt to speak for the many victims of geo-political power struggles.
\end{abstract}


"In a decaying society, art, if it is truthful, must also reflect decay. And unless it wants to break faith with its social function, art must show the world as changeable. And help to change it." Ernst Fischer (1899-1972)

By his own admission, Michael Reed is an artist who is hard to pin down. He displays a magpie's appetite for trying new techniques and new directions in his creative practice, underpinned by a life-long commitment to the ever-versatile medium of print. In a career spanning nearly five decades,

he has never been stuck for ideas or the right ways to express them. He has been exhibiting steadily since the 1970s, often alongside his better-known contemporaries such as Barry Cleavin, Ralph Hotere, Gordon Walters and Don Peebles. ${ }^{1} \mathrm{He}$ is the recipient of numerous national and international awards, and his work, which has been shown in South America, the United States, Europe, Australia, Cuba and Japan, is held in collections all over the world, including the British Museum. ${ }^{2}$ Why then does his name not appear more frequently in New Zealand's mainstream arts publications?

The answer to that question may lay in the fact that the work he is best known for is often politically motivated, international in its focus and print-based. Given the current debates on the political, economic, and environmental future of this planet, it is perhaps timely to broaden current perspectives on this aspect of contemporary New Zealand art practice. Therefore, this article will discuss how Reed, born in 1950, right on the mid-point of the $20^{\text {th }}$ century, responded to certain aspects of growing up and maturing as an artist in New Zealand at that time, and how he moved on from there to acknowledge the cultural and ideological shifts associated with the rise of neo-liberal politics and post-colonial thinking. To this day, he brings to his work the necessary personal attributes required of an artist intent on delivering uncomfortable messages. He has been described as "tenacious, methodical and uncompromising" and he freely admits that the production of "visual sedatives for the established middle-class art print market" 5 is not for him. At 71 , he is still not ready to bend to the prevailing trends of New Zealand's art market and continues to lend his voice to those not often heard in the ongoing global debates on social justice.

In the first instance, Reed's instinctive and often very overt responses to recent historical shifts need to be considered in the context of his upbringing in post-war New Zealand. His interest in art and design did not develop against a comfortable middle-class background, and the social context of Christchurch in the 1950s and 60s provided little encouragement or inspiration in that regard. His recollections paint a rather restrained picture of his younger years, largely devoid of the opportunities a more privileged set of circumstances may have been able to provide for a child with artistic sensibilities. His working-class parents expected him to leave school at fifteen. His father especially thought of his adult son as over-educated, obviously sensitive to the class divide that was opening up between them. That said, his parents' left-leaning political views explains the trajectory of much of Reed's later work.

Reed's art training began at Hillmorton High School, located in the south-east of Christchurch, and one of the many public high schools established in 1960s New Zealand to meet the educational needs of the baby-boomer generation. ${ }^{6}$ To this day, Hillmorton High School carries no particular prestige in a city where the colour of one's school tie forms the basis of significant social and economic networks. It was there that Reed had a lucky break insofar as his art teacher was Ray Neumann. In Reed's own words Neumann was 'a god-send'7 enthusiastic, supportive, tolerant, and a decisive influence. He introduced Reed to a wide range of pre-dominantly European artists, including the so-called Kitchen Sink School of British post-war social realism, and especially John Bratby. Neumann also encouraged Reed to study the work of Gustav Klimt, Egon Schiele, Oskar Kokoschka, the German Expressionists and David Hockney, and showed him examples of Scandinavian modernism to feed his student's early interest in architecture. He was also Reed's first printmaking teacher, introducing him to the linocut, woodcut and screen-printing on textile. Although somewhat sceptical of academia himself, Neumann encouraged Reed's educational aspirations, and perhaps most importantly, he persuaded Reed's parents to let their son stay on at high school past the age of fifteen. This was helped by the fact that Reed, who was otherwise a less than enthusiastic pupil, completed the Fine Arts Preliminary (then the equivalent of bursary art covering sculpture, design, painting, drawing and some photography) during sixth form, and, having received a studentship at the end of that year, transferred to the Ilam School of Art at the age of seventeen. ${ }^{8}$

Reed did not arrive at Canterbury University with any fixed notion as to what he wanted to specialise in and completed the required general first-year course in $1967 .{ }^{9}$ It was then he met some his better-known peers, including the sculptor Graham Bennett, who was studying photography and design, and Chris Booth, who left llam after the first 
year of study to work for Barbara Hepworth in the UK. His fellow students also included the painters Philip Clairmont, Gerda Leenards, Sally Burton and the photographer Mark Adams. He also came to know some of the older students, including Ross Gray, Gavin and Vivian Bishop, Shona Cowan, Brett de Thier, Peter Ridder and Robyn and Peter Belton. At the time, painting, which had always been a strong department at the llam School of Fine Art was by far the most popular option, ${ }^{10}$ which was one of the reasons Reed decided not to join that class. ${ }^{11}$

In 1968, Reed briefly considered studying textiles, but as that department was shutting down, he chose to follow his interest in printmaking instead. He had previously seen and was impressed by the work of Barry Cleavin, and therefore enrolled in John 'Jack' Knight's printmaking course. Reed remembers Knight (1913-1981) as a competent academic and painter, and as an amiable, but hands-off tutor. It was Derek Mitchell, the only other full-time printmaking student at the time, and ahead of Reed by some years, who was the most supportive and taught him technique, namely intaglio and lithography. At the time, screen-printing was still considered a highly commercial medium, and Reed studied this particular process independently. His minor studies covered graphics, with an emphasis on typography, painting (with Ted Francis) and photography. Being one of two full-time printmaking students greatly appealed to Reed. He respected Mitchell and preferred working on his own, more or less free from the usual art school distractions. That said, Reed did not isolate himself entirely from like-minded people of his generation.

In his first year at university, and in keeping with his left-leaning political views and pacifist ideals, he joined local anti-Vietnam war protests, which precipitated his involvement with the general anti-war movement. To avoid conscription, then still the law in New Zealand, he registered as a conscientious objector. He also began to understand the destructive consequences of racism, and the challenges faced by the United States Civil Rights movement. ${ }^{12}$ However, his developing political awareness did not immediately translate into the politically motivated work of the kind he is now associated with. Instead, his graduation portfolio points to another consistent aspect of his work, an eye for effective composition and a seductive use of colour. An example of this is the award-winning Joybox (1969, intaglio and colour pencil, collection of the artist). ${ }^{13}$ Here a square box set against a biomorphic, embossed background, is accentuated by an eye-catching band of rainbow colours, an approach that resurfaced several other prints of this era. It reflects the

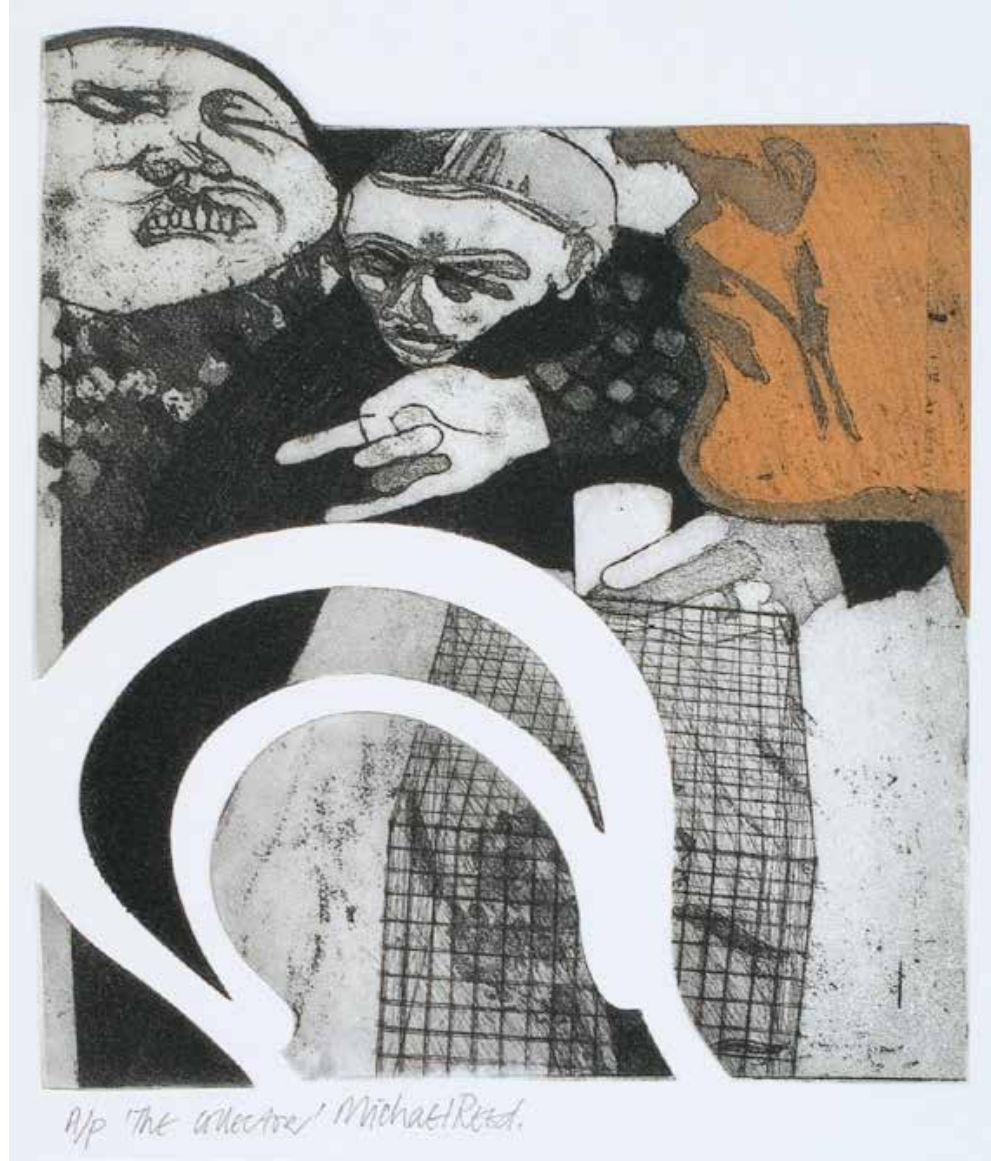

FIGURE 1. The Collector, 1976, etching, 378x557mm, Christchurch Art Gallery Te Puna o Waiwhetu.

artist's interest in British Pop Art, which also appeared in some of the compositional elements of The Collector (Figure 1). This early intaglio work combines figurative elements with an ambiguous organisation of pictorial space, and the use of block colour as a balancing element. By the 1970 s then, Reed had developed a standard of technical competence in printmaking that allowed him to mix various printmaking techniques in at times complex compositions based on expressive mark making.

Reed's concern for social justice first appeared in his work when he began to support Trade Aid in the late 1970s, and more notably so during the Springbok Tour of 1981. At the time he not only joined the protest movement but also designed and printed a poster for a Christchurch protest march. The wordless placard shows a solemn African woman and three undernourished children, their eyes highlighted 
by white paint, added in by some of Reed's students at Christchurch Polytechnic (Figure 2). ${ }^{14}$ In its composition, illustrative style and evocative use of the human figure,

this work recalls Käthe Kollwitz's moving commentaries on the effects of poverty and social injustice on women and children. As Elizabeth Rankin has pointed out, "this style of expressive naturalism carried an accessible message about black suffering that did not need any text to convey compelling reasons for opposing apartheid. Moreover, so many repeated images produced considerable visual impact at the subsequent march...." ${ }^{15}$ Although initially designed as a simple piece of ephemera, the modest poster is now a compelling reminder of an important chapter in New Zealand's social history.

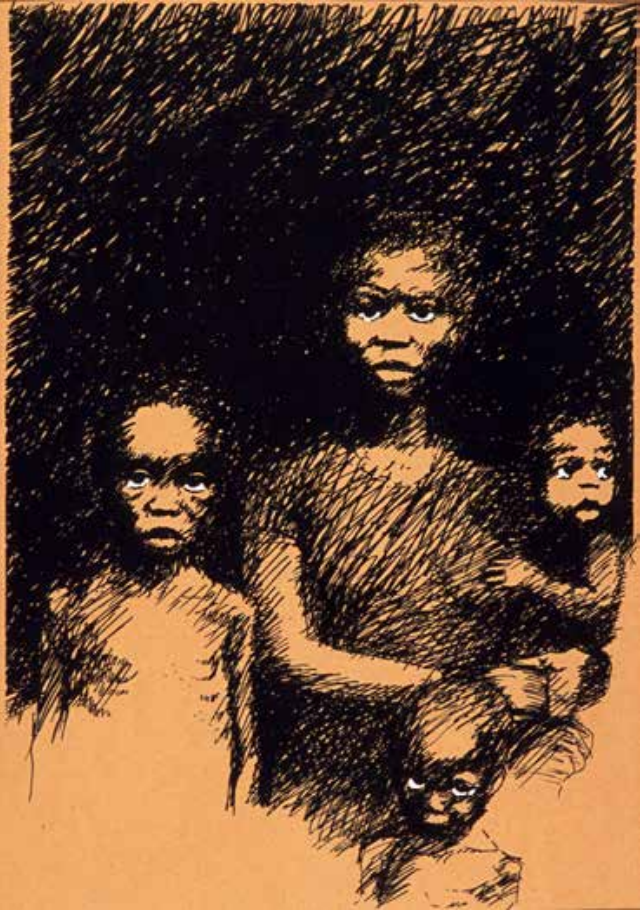

FIGURE 2. Springbok Tour, 1981, screen print and white paint, $950 \times 690 \mathrm{~mm}$, Christchurch Art Gallery Te Puna o Waiwhetu.
At the time, Reed also sympathised with the New Zealand Values Party and sporadically so with Greenpeace, but he has given his most consistent support to World Vision projects in rural Malawi. Throughout his engagement with public agents of social change, however, he elected to stay in the background. Any involvement with mass movements or crowds of any kind is not for him. A naturally reticent person, he still tries to affect change at a personal level, and to this day his art remains his most potent means to express his political and environmental messages. By his own admission, it was teaching at the School of Art and Design at the Christchurch Polytechnic (later CPIT and now the Ara Institute of Canterbury) which gave him the freedom and the opportunity to do and say with his art what he wanted. At times teaching also pushed his work into new directions.

A good example of this is his engagement with Pacific Studies. In the late 1980s and early 1990s, Reed wanted to provide some relevant local design context for his Māori and Pacific Island students. Encouraged by his first hand-study of Polynesian artefacts in museum collections, but also by international examples of cross-cultural art practice, as seen in Eduardo Paolozzi's exhibition Lost Magic Kingdom, ${ }^{16}$ he had grown to admire the various design traditions of the Pacific region, especially in the form of tapa cloth..$^{17}$ It was at this time that he also became fully aware of the lasting effects of colonial rule on indigenous peoples, and how Māori especially had been stripped of their cultural identity. This is just one of many similar episodes in Reed's teaching career where his concern for his students' success led him to invest many hours of extracurricular research to expand his own understanding of social history, visual cultures, and design techniques he had previously not been familiar with. From the beginning then, the setting of Reed's political and moral compass, his natural curiosity, his work ethic and commitment to independent learning not only shaped the constantly evolving nature of his art and design practice, but also the educational outcomes of his students. His teaching philosophy at both diploma and degree level emphasized collaboration, and the recognition that teaching can be an aspect of socially engaged art practice. A teaching studio creates opportunities for specific forms of creative collaboration designed to benefit particular communities, and in Reed's case this included many generations of students from a variety of social and ethnic backgrounds.

In the late 1980 s, fellow printmaker Barry Cleavin noticed that an assertive and particular voice was beginning to emerge in Reed's work and he later likened Reed's prints and drawings to Venus flytraps - alluring to look at, but 


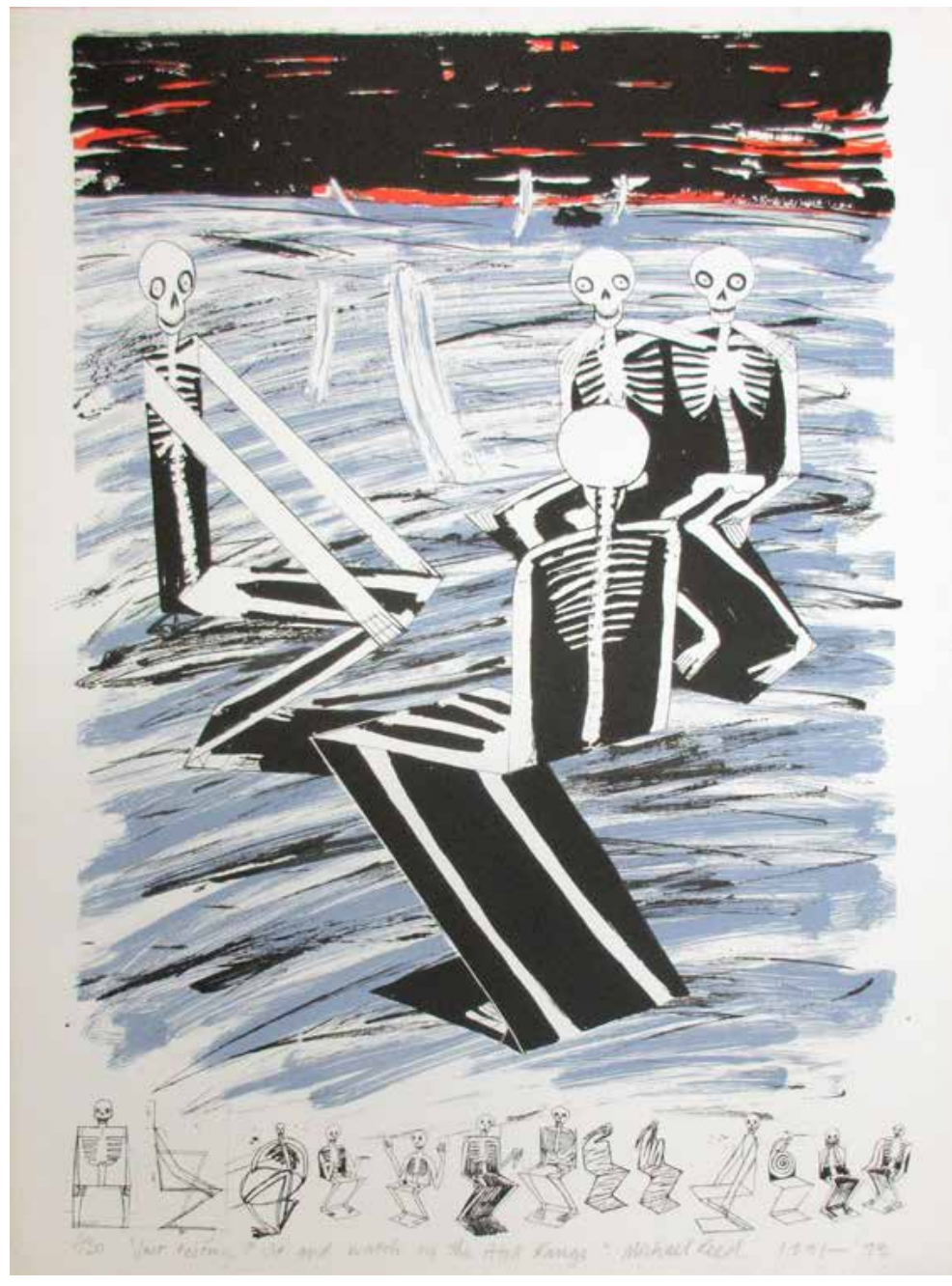

is Just Testing? Sit and Watch on the Atoll Range (Figure 3 ), which responds to the exploitation and destruction of Pacific Island territories at the hand of the world's superpowers. Sitting and watching in this instance are a group of skeletons, recalling in their self-satisfied pose photographs of American navy personnel relaxing aboard their war-

ships next to their contaminated nuclear Pacific test sites. The skeletons, suggestive of the deadly consequences of witnessing such tests at close range, appear to be fused to chairs based on Gerrit Rietveld's famously uncomfortable Zig-Zag design classic. often dangerous on closer inspection..$^{18}$ At that time, Reed became more overt in his political works, "against a trend in art featuring diffuse slogans that could mean anything to anybody." ${ }^{19}$ As a direct result of his growing dismay about European and American nuclear testing in the Pacific, he developed a visual vocabulary that left little room for speculation, and once again he followed the example set by Goya and Kollwitz. He cites both these artists as enduring influences, but also the Mexican muralists, especially David Alfaro Siqueiros and José Celmente Orozco. During a trip to Mexico in 1987 he had seen their work firsthand and he also discovered the visceral symbolism of Mexican folk art the muralists themselves had drawn on. Proof of the deep impression the blunt iconography of Mexican art left on him
FIGURE 4. Anxious Islands, 1990, screen print, photocopy, intaglio and shellac, $586 \times 152 \mathrm{~mm}$, private collection.
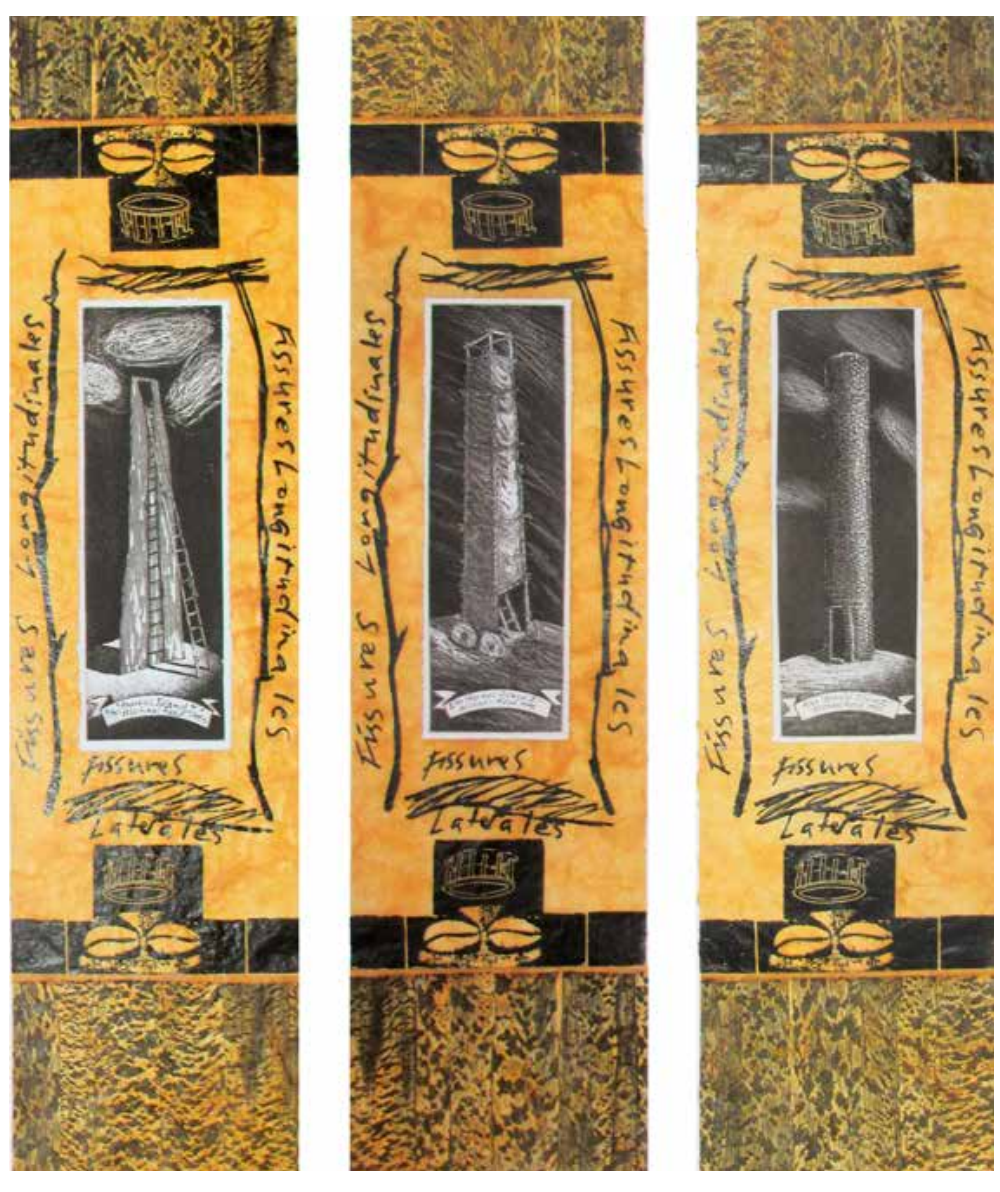
A more subtle comment on the same topic is the Anxious Islands suite (Figure 4), a trio of mixed media assemblages. They combine intaglio work with screen printed backdrops referring to the iconography of traditional Pacific Island art, and a formerly classified French army map which documented the damage done to Moruroa Atoll during French nuclear tests in the Pacific. This is the first of his printed suites to feature typographic elements, quoting from the French map where it highlights 'les fissures laterales' the cracks that appeared in the island's landmass because of the tests. Reed portrays the fragility and makeshift nature of subsistence economies in some parts of the Pacific through a combination of rickety ladders leaning against insubstantial towers, which themselves perch on small, diminishing fragments of land. Here the nature of the etched lines is as delicate as the ecosystems they reference, and the watchtowers remind local populations to remain vigilant in the face of further outside interference in the South Pacific. As borne out by Anxious Islands and Just Testing, by the late 80 s and early 90 s, Reed had become less tethered to Western notions of what constitutes the centre and the margins of global culture. In that sense, his work also articulates aspects of a late $20^{\text {th }}$ century post-colonial enquiry into the complex legacy of two-hundred years of foreign intervention in the Pacific region. Neither Just Testing, nor the Anxious Islands suite enjoyed any form of popular success, and this came as no surprise to the artist. The political left, he realised, does not buy art - the rich do, and few of them want to be critiqued for their tastes or their social affiliations. Despite, or perhaps because of this, Reed continued to pursue a direction in his art that set out "to snag the viewer's eyeball and their mind." ${ }^{20}$

Apart from the uncompromising mind-set Reed shares with many of his national and international collaborators such as Sandra Thomson, Diane Victor or Dan Heyman, ${ }^{21}$ Anxious Islands in particular points to another thread within Reed's multi-directional work of the last thirty years. He insists on staying well informed on global issues when the easier option would be to seek refuge in matters of style and technique. He was quick to pick up on the late $20^{\text {th }}$ century realisation that the world's ecosystems are fragile and under threat, but also interconnected. He reflects on the fact that even in face of diminishing natural resources, the human capacity for greed appears to be infinite. Infinite, too, is humankind's capacity for violence in the pursuit of political and economic advantage. In all of this, Reed draws comfort from the fact that art can, and always has, expressed all aspects of the human condition. Responding to whichever artistic tradition he is investigating at the time, he adds his voice to those who use their art to bear witness, to question, to pause and reflect. As the artist himself stated in 2005: "History provides the proof that creativity is often omnivorous. Art is not necessarily respectful of current social and political niceties or a comfortable commodity. No creative individual operates completely within a vacuum and cultural membranes are permeable. The creative practitioner is a combination of inclination and opportunity." ${ }^{22}$ Inclination and opportunity are, of course, determined by historical and geographical context, as well technological developments. Reed's work reflects how the digital revolution of the later $20^{\text {th }}$ and early $21^{\text {st }}$ century has drawn New Zealand much closer to globalised patterns of cultural expression distance no longer looks our way the way it used to. ${ }^{23}$ And yet, while digital communication technology and contemporary modes of transport transcend some of the former boundaries of time and space, New Zealand remains largely unaffected by the maelstroms of history that destroy entire countries elsewhere in the world. Reed knows this, he is aware of his own privileged circumstances, however humble his background and lifestyle may appear to others looking in. "In New Zealand" he says, "life is about the quality of your existence, not whether you exist at all." ${ }^{24}$

It is this awareness that encouraged him to shift his focus from the foreign exploitation of the Pacific region onto those who profit the most from keeping the world ensnared in a climate of political unrest. Following a theme first raised in Feeling Blue and Seeing Red (1995-97, screen print, 446x1188mm, Christchurch Art Gallery Te Puna o Waiwhetu), a self-portrait which includes on the left-hand side of a screen-printed diptych the 54 armed conflicts which were being fought in the world at the time, Reed began to investigate the global arms trade. In other words, he decided to take an unflinching look at the impact the first-world production of and trade in weapons has on predominately third-world countries. This is not easy to do, as the topic is hard to digest and could persuade anybody to give up on humanity altogether. Instead, Reed chose the global arms trade as the subject for his MFA, which he completed at Canterbury University in 1999. Submitted alongside a research essay entitled The Art of Counter Attack, this body of work shows Reed at his most defiant. In an installation comprising seven predominantly large-scale works, he pulled no visual punches as he took to task the international merchants of death. They remain sheltered by their wealth, political influence and laws protecting their industry, while elsewhere entire communities are killed, maimed or rendered homeless by their products. 


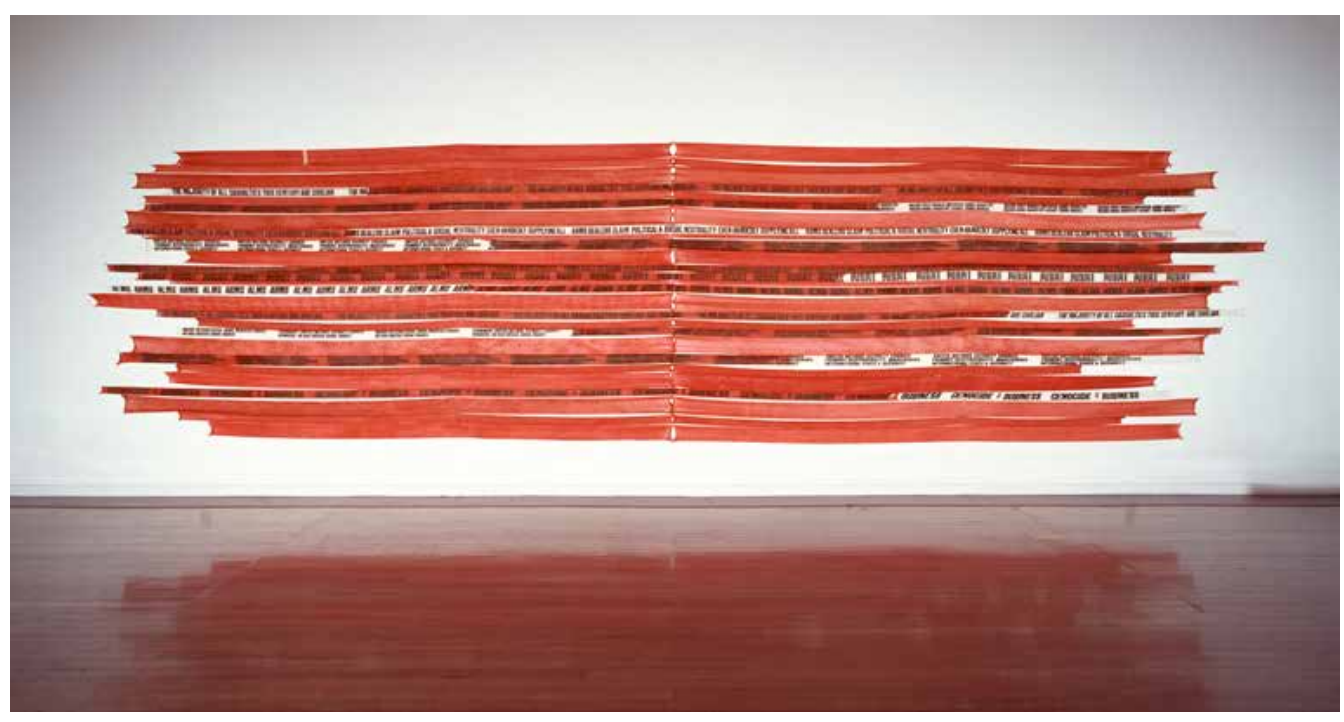

FIGURE 5. Binding Statements, 1999, silk screen on

dyed cotton crepe bandages, $3000 \times 9200 \mathrm{~mm}$, Collection

of the Christchurch Art Gallery Te Puna o Waiwhetu.

The best-known piece of this suite of works is Binding Statements (Figure 5), where Reed printed several sobering statements regarding the effect and size of the international arms trade onto a collection of blood red bandages. Overall, this was a difficult exhibition to view because it upended any audience expectation of the gallery as a place of polite entertainment. That said, in 2001, Helen Clark, then Prime Minister of New Zealand, chose Binding Statements as her favourite work in the Christchurch Art Gallery collection. ${ }^{25}$ It also provided the starting point for a later piece on a similar theme. Maim Radius (Figure 6), is one of a pair of works of similar content, which highlights the factual, yet ultimately callous language used in the promotional material published by arms manufacturers. Based on an A3 sized assemblage of printed bandages layered with burned acetate, Maim Radius alludes not only to the lethal effectiveness of the products available at arms fairs, but also to the human cost of their deployment. The initial assemblage was photographed by Reed's former colleague Murray Hedwig, and then digitally printed at a much larger scale to further link the image to the promotional banners commonly seen at arms fairs.

The fact that Reed can deliver potent messages in any variety of formats is further borne out by his medallions, which have received international attention. ${ }^{26}$ Reed first exhibited a medallion at the 1991 New Zealand Contemporary Medallion Group (NZCMG) show, at the invitation
Banbury. He has contributed to national and international exhibitions of the NZCMG ever since and began to participate in Fédération Internationale de la Médaille d'Art (FI-

DEM) exhibitions in 1996. Reed was conscious that he would find the traditional shape of medallions challenging, as by his own admission he does not like circular formats. ${ }^{27}$ That said, given the thematic trajectory of his work in the 1990 s, the medallions very soon morphed into openly subversive 'medals of dishonour,' reminiscent at times of the mid-20 th century anti-war medals by American sculptor David Smith (1906-1965). ${ }^{28}$ 'Medals of Dishonour' was also the title of a 2009 exhibition at the British Museum. It showcased their

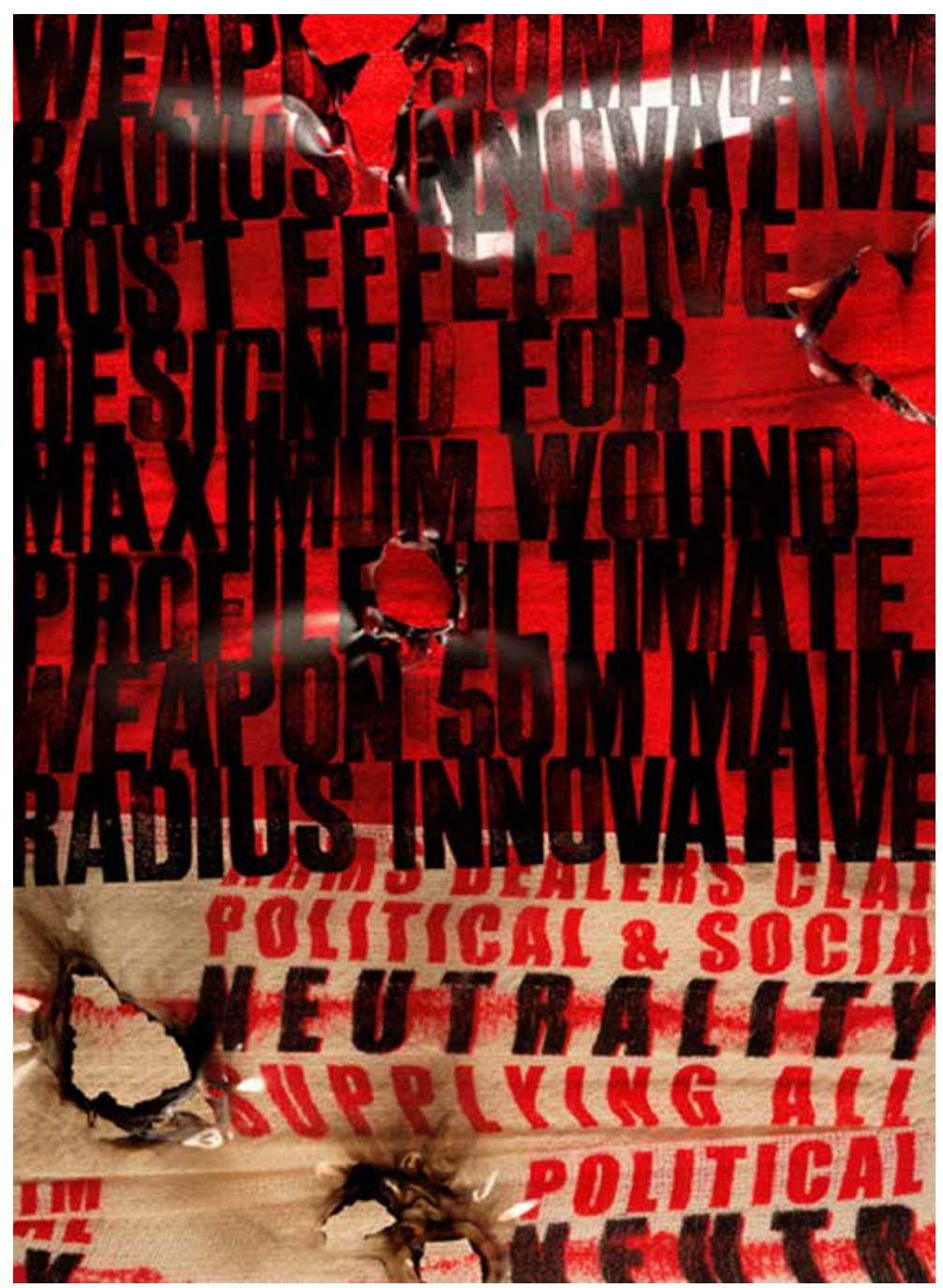

FIGURE 6. Maim Radius, 2007, digital inkjet print on paper, of a screen print on cotton crepe bandage and photocopy on acetate, $1465 \times 1092 \mathrm{~mm}$., collection of the artist. 


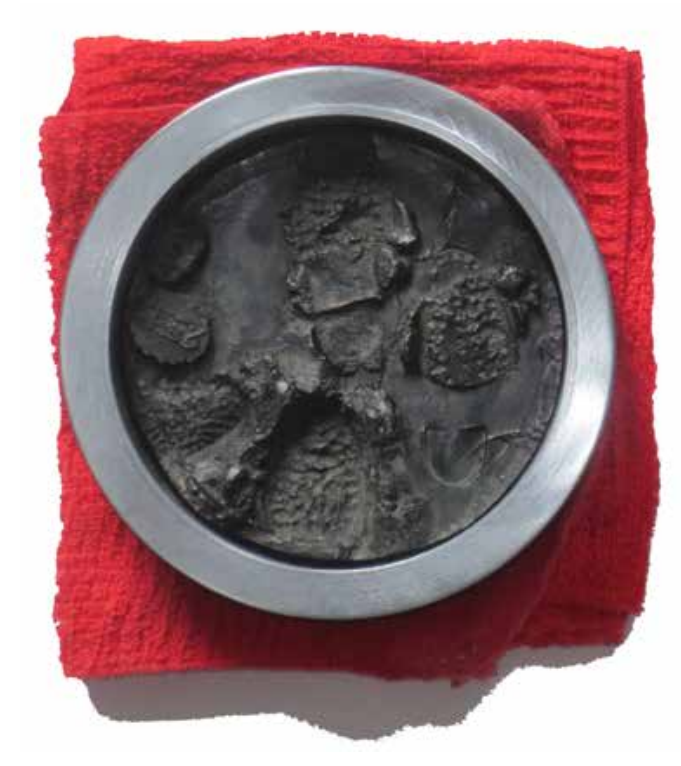

FIGURE 7. WWI Flanders/Mud Beneath their Boots (Fig. 8, 2017, cast bronze and turned steel, $128 \mathrm{~mm}$ diameter, height $34 \mathrm{~mm}$. Collection of the artist.
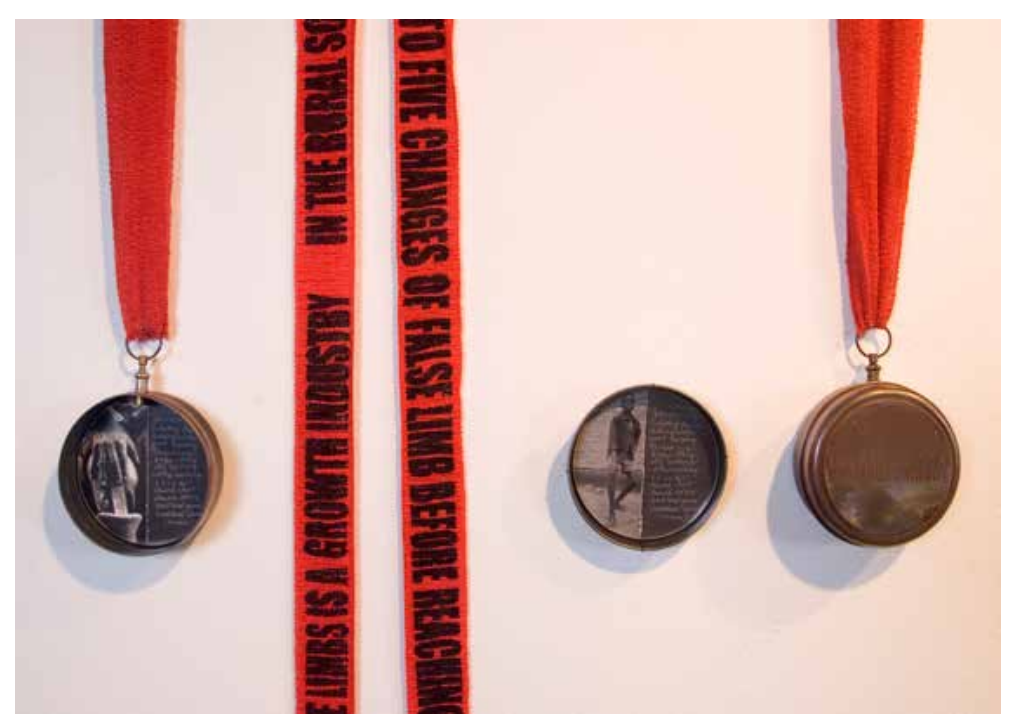

FIGURE 8. Looking Back, Looking Forward / An Award for Manufacturing, 1999, assembled found metal tin and metal fitting, silk screen and photocopy on paper,

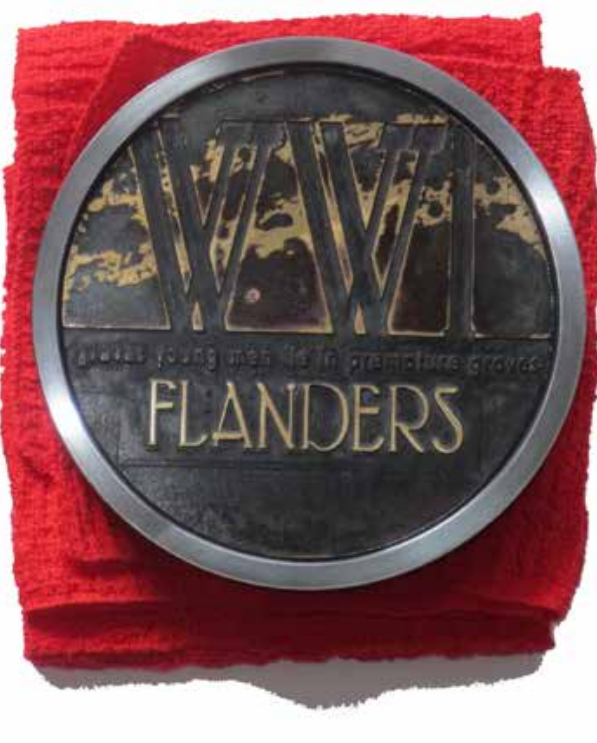

$110 \mathrm{~mm}$ diameter, and silk screen on cotton crepe ban-

dage, British Museum. special-interest collection of subversive medals, some of which date back to the $17^{\text {th }}$ century. ${ }^{29}$ As of December 2017 , the British Museum owns four of Reed's medals, which puts him in illustrious company. For the 2009 exhibition, for example, they commissioned works by renowned international artists such as Jake and Dinos Chapman, Ellen Gallagher, Grayson Perry, and William Kentridge. ${ }^{30}$

The medals provide Reed with an ideal vehicle for his persistent and often confronting protests against all forms of violence and exploitation. From the beginning, he used the double-sided nature of the medallion to show the two sides of each issue he chooses to comment on. Moruroa/ Mururoa1 (1991, cast bronze, $88 \mathrm{~mm}$ diameter, private collection), like Anxious Islands, contrasts the dispassionate mapping of the effects of French nuclear testing at the atoll, as seen on the obverse of the medal, with the anguished portrait of an islander rendered homeless by this callous act of environmental destruction. Similarly, Trickle Down Economics/ Life under The Round Table (1993, cast bronze, $90 \times 120 \mathrm{~mm}$, British Museum) summarises the false promises of neo-liberal economic policy. On the obverse, a pair of business men fill each other's plates with a steady flow of profits, while on the reverse a woman crouched under the round table holds up an empty bowl.

In the 1990s, Reed's medals engaged not only with global instances of social injustice, but also satirised the context conventional medals are usually related to. As observed by John Freeman-Moir, "medals awarded by the state are symbols of convention and conformity" ${ }^{31}$ and serve to perpetuate the ideological status quo. Therefore they can be easily subverted to do exactly the opposite, namely to protest against oppressive regimes of all political persuasions and state sponsored violence in the shape of wars of aggression. Reed's 'medals of dishonour' do just that, and often in a highly experimental manner. Military Wisdom (1995, cast bronze, $113 \times 100 \mathrm{~mm}$, collection of the artist), like Trickle Down Economics/Life under The Round Table, abandons the shape of the traditional medal, and instead takes on the guise of a skull in profile, adorned with a laurel wreath supplemented with missiles, and rows of teeth consisting of machinegun cartridges. Looking Back, Looking Forward/ An Award for Manufacturing (Figure 7), sees Reed expanding on the visual and technical repertoire developed during his MFA year, with the medallion's printed 'ribbon' explaining as to who profits and who suffers from the business of war. The past manufacturers of landmines re-join the side of the winners, as they are paid a second time to dismantle the product they originally supplied. While for much of the 1990s 
Reed concerned himself with the politics and commercial interests underpinning $20^{\text {th }}$ century warfare, a medal he produced more recently served to commemorate the fallen of World War One and the approaching $100^{\text {th }}$ anniversary of Armistice Day.

WWI Flanders/ Mud Beneath their Boots (Figure 8), is a melancholic tribute to the casualties of the 'Great War.' The obverse features a small line of text, quietly lamenting the countless young men who 'lie in premature graves.' The boot prints pictured on the reverse were inspired by Alan Marriott's Mud Beneath My Boots, based on the moving wartime recollections of his uncle Len Coley. ${ }^{32}$ Reed decided that whichever side the combatants were on, the mud beneath their boots was a shared experience. Using a photograph supplied by the New Zealand Army Museum as a reference point, Reed created miniature versions of a New Zealand soldier's boot soles, and 'marched' them through the damp clay of his casting mould. This side of the medal is deeply inset within the turned steel cylinder that frames the work, to relate the image further to the muddy depths of Flanders' trenches. The steel outer surface retains its manufacturing and handling patina to allude to the barrel of a weapon that has seen action.

Another one of Reed's more recent medallions is entitled 'Me First- The Trump Award for Outstanding Greed, Unsullied by Ethics (2017, cast bronze, 100 mm diameter, British Museum). Here a seemingly respectful portrait of the former American president seen in profile is undermined by the medal's name inscribed on the reverse. ${ }^{33}$ It warns about the dangers inherent in the unpredictable and apparently self-serving presidency of Donald Trump. What all the medals demonstrate is that Reed can adjust his compositional approach, and especially the use of figurative elements to any scale, and that even the most conservative and traditional of genres can accommodate and benefit from creative experimentation. The medallion work is a good example of the artist confronting his instinctive dislike of a particular format, and as a result arriving at a near perfect medium to convey a variety of messages.

To the medallions and the politically inspired prints of the 1990s, he later added the equally uncompromising Runners for the Corridors of Power (2009, digital dye injection on nylon, $4000 \times 1000 \mathrm{~mm}$, collection of Dilana) ${ }^{34}$ pro-

duced in conjunction with Dilana Rugs, and a set of punchy Drapes for Real Men (2009-2011, screen print on textile, $5000 \times 1600 \mathrm{~mm}$, collection of the artist). Both sets of works received some scholarly attention alongside other, national and international examples of politically motivated art. ${ }^{35}$

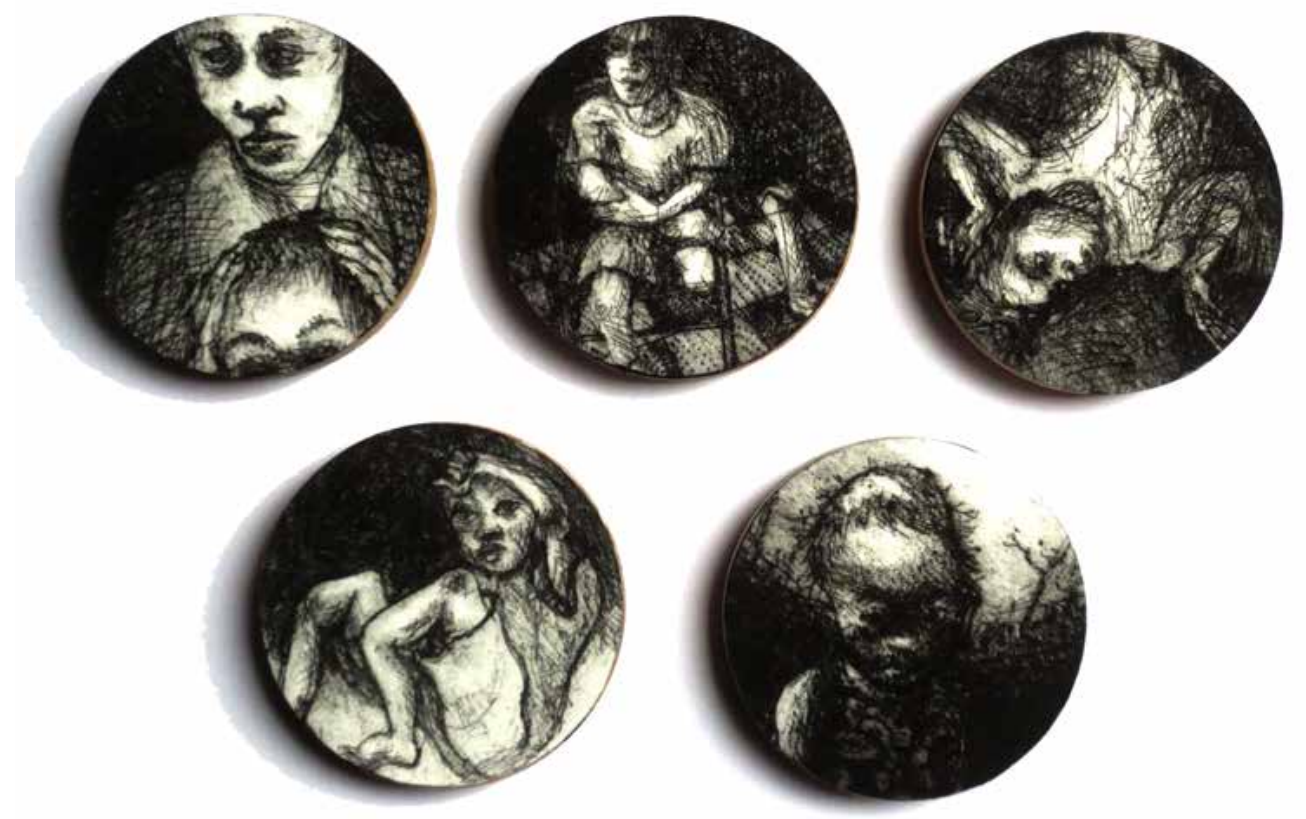

FIGURE 9. By-product 2018, digitally printed paper, dry point and metal tins, $3000 \times 900 \mathrm{~mm}$ private collection.
This highlights the way Reed built his international network of contacts. Through print collaborations and international print workshops, he linked up with a community of like-minded artists who look towards the centres of printmaking excellence for inspiration and who continue to build on the tradition of printmaking as a medium of protest and social commentary.

That same network facilitated Reed' participation at Impact 10, in Santander, Spain in 2018. The large format of Drapes for Real Men anticipated Reed's contribution to this particular show. By-product is an installation which consists of a monochromatic and digitally printed length of paper in combination with 5 small format, circular drypoints. It was exhibited at Impact 10 as part of a group project called Encountering Our Indelible Mark, initiated by American artist Blake Sanders (Orange Barrel Industries). ${ }^{36}$ By-product expands a concept first explored in the medallion Endowment (2017, engraved aluminium, digital printing on paper and 


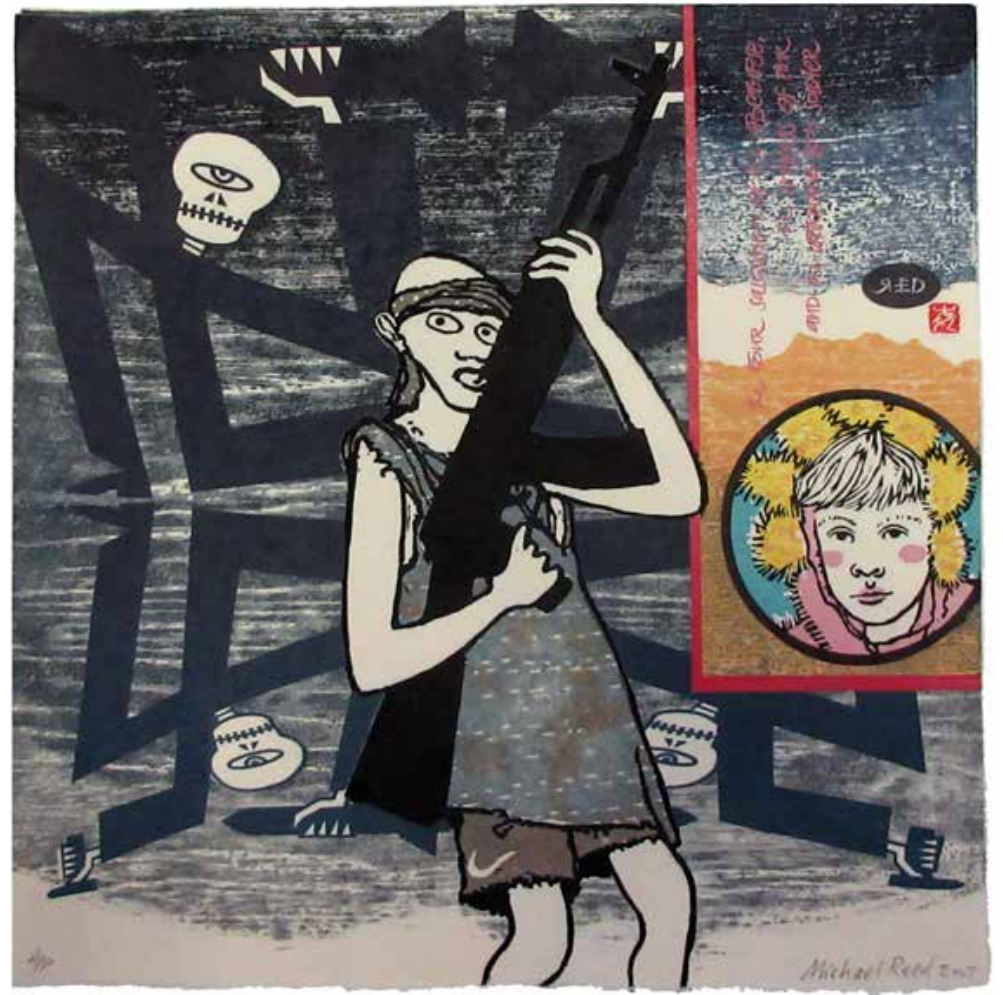

FIGURE 10. The Four Salesmen of the Apocalypse, the rincess of Pink and the Unknown Boy Soldier, 200

collection of the artist.
FIGURE 11. Kai Aku Rika, 2013, screen print, $470 \times 370 \mathrm{~mm}$, private collection.

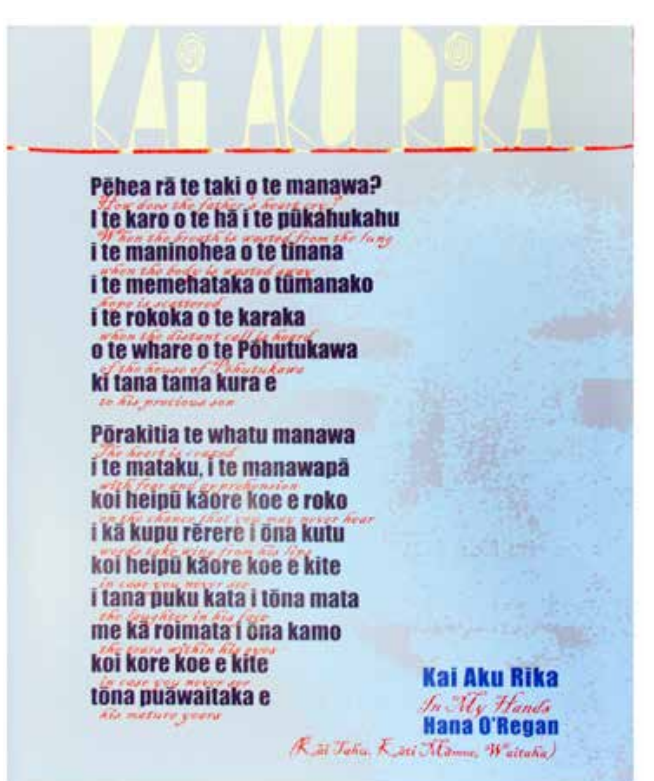

cast bronze) ${ }^{37}$ and once again demonstrates Reed's effective use of a wide range of techniques and formats within a unified whole.

In By-product, the droplets depicted on the large print are graduated in size and tone, containing fragments of the chemical formulae for the so-called rainbow herbicides used in the Vietnam War. The same formulae feature in their complete form on the rainbow-coloured labels on small tins mounted alongside the large print. The monochromatic drypoints inside the small tins depict some of the deformations suffered by Vietnamese child victims of the defoliants (Figure 9). The focus of both Endowment and By-product then is the long- lasting intergenerational effect of chemical spraying by the US Army during the Vietnam War. The recipe of the defoliants varied over time and from manufacturer to manufacturer. Legal battles for compensation continue, involving US army veterans and the Vietnamese victims of the contamination, but also soldiers from other countries such as New Zealand. As alluded to above, Reed was in his mid-teens when the Vietnam War commenced. To this day he remembers a high school classmate who joined the New Zealand army and ended up fighting in Vietnam, while he went off university, participating in anti-war marches and registering as a conscientious objector. ${ }^{38} \mathrm{By}$-product not only alludes to one of the many American wars fought on foreign soil, but also to the social divisions it caused in New Zealand and its long-term impact on New Zealand veterans.

Similar themes reverberate in his contributions to a number of international print portfolios, especially those initiated by Melanie Yazzi (Boulder, Colorado), and his submissions to exhibitions in Estonia, the United States, Spain, Cuba, Mexico and the United Kingdom..$^{39}$ The international recognition Reed enjoys as an artist rests almost solely then on his works of protest, in countries where audiences arguably have a greater appreciation of art that sets out 'to snag their eyeballs and their minds.' As implied above, Reed greatly increased his professional profile through his contributions to sixteen multi-national print portfolios, covering a range of themes and printmaking techniques. This included A time and place Nagasawa 10, an artist exchange portfolio, on the theme of a time and place of significance. Some of the contributors had first met in 2002, when they attended the artists-in-residence programme at Nagasawa on Awaji Island, Japan, to learn Japanese printmaking techniques. Reed had applied for the residency as an extension of his life-long interest in Japanese visual culture, and he particularly enjoyed his later collaborations with the international group of printmakers he met there. The portfolio was 


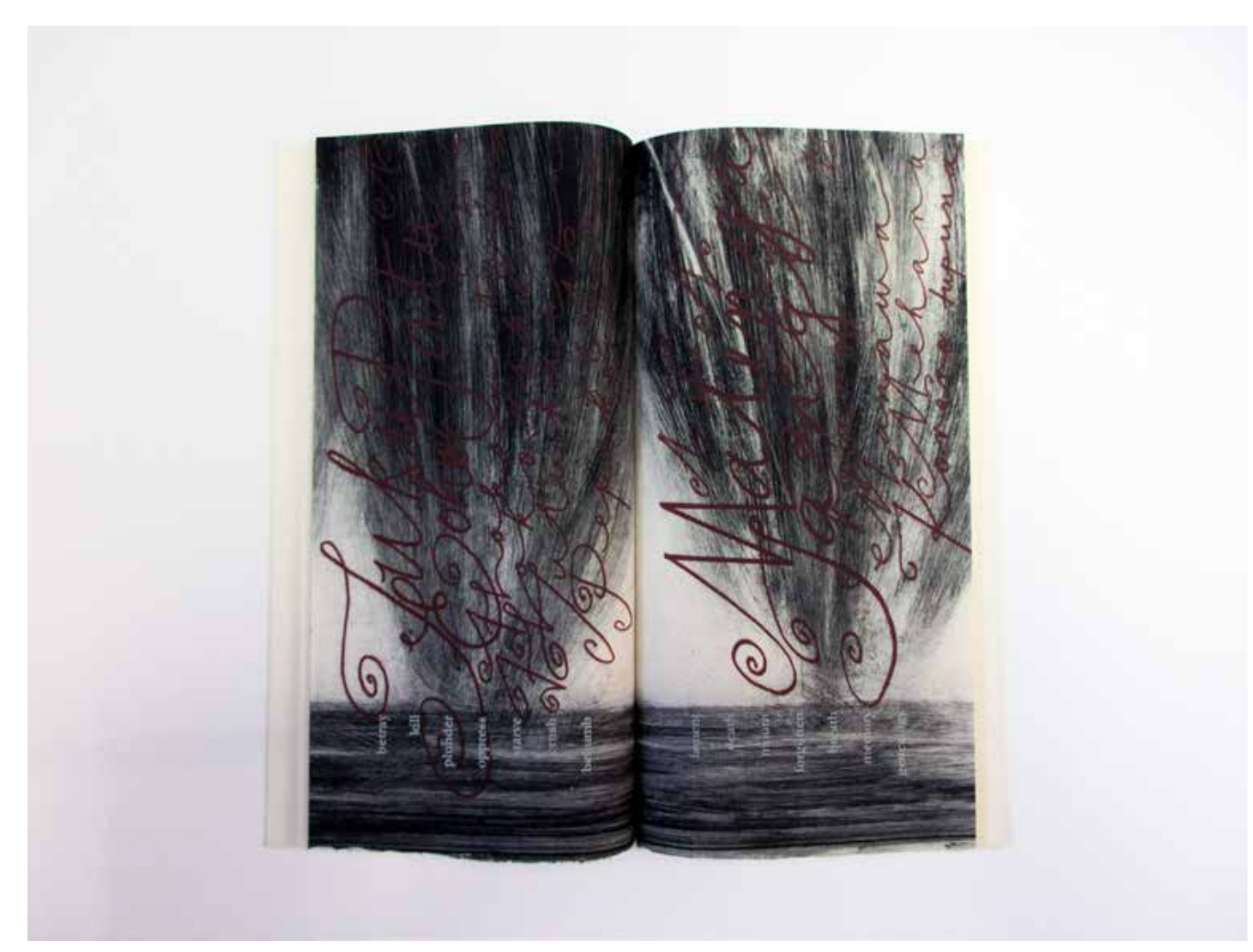

FIGURE 12. Man Disappears, 2002, Michael Reed: 3 double-spreads, drypoint, etching and screen print; $255 \times 130 \mathrm{~mm}$ paper size, double-spined boune Mellor: typesetting and binding.

initiated and co-managed by Reed and the Dutch artist Nel Pak. Reed also designed and printed the written material which usually accompanies projects of this nature. Reed's contribution was The Four Salesmen of the Apocalypse, the Princess of Pink and the Unknown Boy Soldier (Figure 10). The work is one of just a handful of prints where Reed applied what he had learned in Nagasawa. It combines Japanese modes of composition and woodcut techniques with screen print and continues the familiar anti-war message, pointing out his dismay at the rising number of child soldiers. Their fate contrasts sharply with that of 'The 'Princess of Pink', captured in a small circular inset. This is a portrait of Reed's then four-year-old granddaughter, whose angelic features suggest a very different childhood experience.

In 2009, Reed re-visited the mokuhanga technique in Surimono International, another international exchange portfolio collaboration with alumni of the Nagasawa artists-in residence programme. It was exhibited that year at Impact 6 in Bristol, alongside a further international print portfolio Reed contributed to, entitled Another New Zealand, Another United States. He co-initiated this particular portfolio with Melanie Yazzi, but Reed also edited, designed and produced the accompanying statements and printed the contributions made by New Zealand artists Riki Manuel, Glen Stringer and Wayne Youle. Reed's Too Much is Never Enough (2009, screen print, $510 \times 405 \mathrm{~mm}$, Collection of Ara Institute of Canterbury) critiques the clean and green image of New Zealand and takes issue with the pollution caused the country's expanding dairy industry. But apart from his commitment to the art of protest, the portfolio also points to another enduring feature of Reed's practice, and that is his willingness to support the creative projects of fellow print makers. This includes the mentoring of younger artists, as many of the contributors to the various exchange portfolios Reed has been involved with are his former students. ${ }^{40}$

At times his collaborations also extended beyond his immediate professional networks. For the Crossing Paths international exchange portfolio, he joined forces with Hana O'Regan (Kāi Tahu, Kāti Māmoe, Waitaha) then a senior academic at Christchurch Polytechnic. Kai Aku Rika (Figure 11), superimposes O'Regan's bilingual poem Kai Aku Rika - In $M y$ Hands onto a faint portrait of a young boy. In this work, the written word takes centre stage, while the image has only a supporting role to play. The poem's English version appears in the cursive script favoured by $19^{\text {th }}$ century European colonists, a subtle reminder of the impact European 
Kai Aku Rika belongs to the part of Reed's overall print oeuvre that is less well known. These are the works that strike a gentler tone, but are connected to his more outspoken images in terms of style, technical experimentation and the effective use of colour. Another example of this resulted from a notable collaboration with Canberra-based Czech printmaker Peter Herel. Herel was artist-in-residence at the Christchurch Polytechnic School of Art and Design in 1999 and although the two men could not be more different in

their approach to printmaking, they decided to co-produce a hand-printed, hand-bound book entitled Man Disappears (Figure 12), Based on the research undertaken by New Zealand historian Michael King, this delicate ensemble of prints - Reed's far more vigorous images complementing the subtle tonalities preferred by Herel - recounts the history of the Chatham Island Moriori. A copy of their book is held at the Alexander Turnbull Library and the National Library of Australia in Canberra. ${ }^{4}$

Drawing on just a selection of works from a career spanning five decades, this article highlighted that it is possible to balance a commitment to a New Zealand context with a view that New Zealand, while situated on the geographical margins of the world, is a member of the internationa community, requiring a consistent acknowledgement of those local artists whose work critically reflects on political, social and environmental issues of global significance. As an artist, Reed points the viewer to the less welcome aspects of the human existence, but by doing so highlights again how art, and specifically the sensitive and balanced combination of word and image can capture the complexity of an experience that is otherwise difficult to convey. Reed's life-long commitment to politically motivated art, but also to his largely unacknowledged role as a teacher, facilitator and collaborator has helped him to share human despair alongside hope. His work enabled him to model integrity and a sense of communal and personal responsibility in an age of self-interest, and to appreciate his own privilege while showing empathy for those less fortunate. Reed remains as self-deprecating as ever and networking for the sake of self-promotion is still anathema to him. ${ }^{42} \mathrm{His}$ focus remains firmly on the technical, aesthetic and ethical challenges of whichever project he is working on and he remains an important New Zealand contributor to art in the service of social justice.

\section{REFERENCES} Artists. Auckland: Godwit 1996.

Clark, Helen. "My Favourite" Bulletin of the Robert McDougall Art Gallery, b.1 26, (2001): 4

Cotter, Holland. 'Art Review: David Smith's Anti-Medals' New York Times, January 6, 1995. htip.//www.nytimes. medals.html Zealand, no. 58: 66-69 \& 102-103.

Freeman-Moir, John. “Neither Shall They Learn War Anymore," The Medal, no. 47 (2005): 61-73.

Huie, William Bradford. Three Lives for Mississippi. Jackson: University of Mississippi, 2000

Lyons, Beauvais. "The Exchange Portfolio as a Relational Art Form," Im:Print Zustandsprotokolle Aktueller Druckgraphik (2011): 83-91.

Marriot, Allan. Mud Beneath My Boots: A Poignant Memo of the Effects of War on a Young New Zealander. Auckland, Harper Collins, 2005.

Mclntosh, Jill (ed). Contemporary New Zealand Prints. Wellington: Port Nicholson Press, 1989.

Pauli, Dorothee. “Picturing Peace.” Junctures: The Journa for Thematic Dialogue, no. 14, (2011): 61-74.

Paolozzi, Eduardo. Lost Magic Kingdoms and Six Paper Moons from Nahuatl. London, British Museum Publications, 1985.

Rankin, Elizabeth. "Picturing Protest: New Zealand Artists and the Springbok Rugby Tour Protest,

Journal of New Zealand Art History, no. 28 (2007):18-19. Elizabeth Rankin. "Disturbing Drapes: The Subversive Powers of Printed Textiles," Art New Zealand, no. 134,

Sinclair, Keith (ed.). Distance Looks our Way. Auckland: Auckland University Press, 1961

Riley, Brett. “Shaping Space," New Zealand Listener, February 15, 1986 (not paginated).

Sanders, Blake. "Our indelible mark," 2018.

https://orangebarrelindustries.com/ourindeliblemark/ projects/encountering-our-indelible-mark/ 
1. An early example of this was Artists from the South: Paintings, Drawings, Prints. Brooke-Gifford Gallery,

(hy Cylcers and Joann Paut-

2. See the artist's $\mathrm{CV}$, as of 2017. (Collection of the author) 3. While there have been several journal articles and catalogue essays written about particular aspects of Reed'
works, his name appeared only twice in surveys on New Zealand art. See Jill McIntosh (ed), Contemporary New Zealand Prints (Wellington: Port Nicholson Press, 1989); Warwick Brown, Another Onehundred New Zealand Artists (Auckland: Godwit, 1996). There have been two articles pubished on him in Art New Zealand, one being a review of his MFA exhibition, at the llam School of Fine Arts, University of Canterbury. See Cassandra Fusco, "One Pacific Viewpoint, Pre New Zealand, no 58 (1991). 66-69 \&102-103, Doroth (1999): 46-48. Some of his work also featured in Eliza 91 Rankin, "Disturbing Drapes: The Subversive Powers of Printed Textiles," Art New Zealand, 134, 2010: 52-55.

4. Brett Riley, "Shaping Space", New Zealand Listener, February 15, 1986 (not paginated)

5. Michael Reed, 'A Polemical Post-Script', unpublished essay and documentation supporting a submission in print for a Master of Fine Arts, University of Canterbury, 1999. (Collection of the artist,

6. The Reed's home was zoned for Riccarton High School, and the much more prestigious Boys High School, but especially the latter, with its insistence on tradition and
cadetship rituals, did not appeal at all to him. His family had heard encouraging reports about Hillmorton, and it was thought of as a school with a more modern and liberal-mindd outlook on education. Michael Reed, personal communcation, interview by author, October 27, 2017.

7. Michael Reed, interview by author, August 17, 2016.

8. It was the studentship that made all the difference to him and his parents, as it meant he could undertake his study with some financial independence and look forward author, August 24, 2016.

9. As mentioned, while still at high school, he had an interest in architecture, and even built a number of models, and he had seen some pottery exhibitions in Nelson. Whe he met Steven Foster, a fellow student at Hillmorton, who fifteen or so, Reed too for a while, entertained the nKtion coming an apprentice potter.

10. See for example ArtSchool125, an exhibition held at the Christchurch Art Gallery Te Puna o Waiwhetu to celebrate the 125th jubilee of the llam School of Fine Arts. The exhibition was dominated by the many painters who haduated from the schaolery indexhtom /

11. Michael Reed, interview by author, October $27,2017$. The other reason was that he was not enamoured with the

work

12. In his first generic year of study, Reed attended the following classes:

13. Drawing (figurative and observational), with Eileen Mayo

14. Drawing (technical, and Roman lettering), with Florence Atkins

5. Painting, with Doris Lusk

16. Sculpture, with Tom Taylor

17. Basic Studies (modelled on the Bauhaus 'Grundkurs') with Don Peebles

18. History of Art, with Richard Lovell-Smith

19. History of Architecture, with Tom Taylor

20. Reed had read William Bradford Huie's Three Lives for Mississippi, first published in 1965, and was deeply mpressed by this vivid account of the murder of three Civil a revised edition of this book. See William Bradford Huie Three Lives for Mississippi (Jackson: University of Mississippi, 2000).

21. Reed was awarded the ANZ Bank Award for Contemporary New Zealand Printmaking, 1970, for Joybox, being
co-winner of the award that year alongside Marilyn Webb.

22. See Elizabeth Rankin, "Picturing Protest: New Zealand Artists and the Springbok Rugby Tour Protest", Journal of New Zealand Art History, no. 28 (2007):18-19. The picture is based on a photograph by Don McCullin

23. Elizabeth Rankin, "Picturing Protest", 18. Proof of this is a compelling photograph in Truth, which features a line of police personnel facing a row of the Christchurch protesters
holding Reed's placards. New Zealand Truth, 25 August 1981, front page.

24. See Eduardo Paolozzi, Lost Magic Kingdoms and

X Paper Moons from Nahuatl (London: British Museum in 1989

25. Prior to commencing his MFA, Reed studied Pacific art with Karen Stevens at the University of Canterbury Christchurch Roger Fyfe, currently the Senior Curator Human History at the museum gave him access to many Pacific Island artefacts. A little know screen print which reflects his deep appreciation of Pacific visual culture is Ngarara, (1993, screen print, paper size $420 \times 294 \mathrm{~mm}$, private collection) which not only quotes images and notes taken from his museum sketchbooks, but also features a circle of stylised skinks, panicked by approaching footfall. This, in part, recalls family outings to Quail Island, which introduced Reed's sons o local skinks. Michael Reed, interview by author, August 24,2016

26. Michael Reed, interview by author, August 24, 2016.

27. Michael Reed, interview by author, August 24, 2016
28. Michael Reed, interview by author, 20 March, 2017. 29. See Elizabeth Rankin, “Collateral: Printmaking as Social Commentary,"Takahe, 75, no.1 (2012): $33-40$; Dorothee Dialogue, no. 14, (2011): 61-74.

30. Artist statement, exhibition pamphlet, Pictures with Stories: Stories with Pictures, Chamber Gallery, Rangiora, 2006. (Collection of the artist).

31. See Keith Sinclair (ed.), Distance Looks our Way (Auckland: Auckland University Press, 1961).

32. Michael Reed, interview by author, August 29, 2017.

33. Rt. Hon. Helen Clark (Prime Minister and Minister for Arts, Culture and Heritage) "My Favourite" Bulletin of the Robert McDougall Art Gallery, no.26, 2001

34. See for example John Freeman-Moir, “Neither Shall They Learn War Anymore," The Medal, no. 47 (2005): 61-73.

35. Michael Reed, interview by author, August 17, 2017.

36. For a discussion of retrospective of Smith medals, see Holland Cotter, "Art Review: David Smith's Anti-Medals," New York Times, January 6, 1995. http://www.nytimes.
com/1995/01/06/arts/art-review-david-smith-s-anti-medals.html

37. For a description of the exhibition, see http://www britishmuseum.org/about_us/news_and_press/press_reeases/2009/medals_of_dishonour.aspx

38. http://www.britishmuseum.org/about_us/news_and_ press/press_releases/2009/medals_of_dishonour.aspx

39. John Freeman-Moir, "Neither Shall They Learn War Anymore," 61

40. Allan Marriot, Mud Beneath My Boots: A Poignant Memoir of the Effects of War on a Young New Zealander, (Auckland: Harper Collins, 2005).

41. The Medal, no.71, (2017): 70

42. See Elizabeth Rankin, “'Collateral: Printmaking as Social Commentary," Takahe, 75, no.1 (2012): 33-40.

43. Reed's Drapes for Real Men, another unflinching indictment of the arms industry, were exhibited as part of 'Drape', an exhibition at CoCA, also featuring the work of Katharin Arts Festival, 2009. See Elizabeth Rankin, "Disturbing Drapes: the Subversive Powers of Printed Textiles," Art New Zealand, 134, 2010: 52-55. One of the works (alongside a later example) also featured in Collateral: Printmaking as Social Commentary, Gus Fisher Gallery, 1 July - 20 August 2011. (Curated and catalogue written by Elizabeth Rankin. ine two Runned in this exhibition, as well as in 'Giviner f Dissent', Salamanca Art Centre Tssmani, 1 August - 14 September 2014.

44. See https://orangebarrelindustries.com/ourindeliblemark/projects/encountering-our-indelible-mark/

45. See https://michaelreedprint.wordpress.com/medal-
46. Michael Reed, interview by author, February 12,202 47. For a discussion of the significance, function and g popularity of exchange porttolios, see 48. A further example of Reed using an international exchange porfolio to mits Re ed works by Reed, and his former students Hannah Page, Ben Reid and Sam Reed. These three artists were included at the request of Melanie Yazzi. That said, it is outside the parameters of this essay to fully analyse the legacy of Reed's teaching career.

49. At the time, Reed considered his collaboration with and a much-valued learning opportunity regarding the technical and aesthetic aspects of printmaking. Michael Reed, interview by author, December 30, 2017.

50. Aware of the limited commercial appeal of his more recent work, Reed has not approached dealer galleries for 